日臨外会誌 $65(9), 2315-2318,2004$

症例

再手術時に反回神経再建術を行った再発進行甲状腺癌の 1 例 土谷総合病院外科, 広島大学第 2 外科*

$\begin{array}{llllllll}\text { 川口 } & \text { 康 } & \text { 夫 } & \text { 野 圭 三 西原 雅 浩 } \\ \text { 矢 } & \text { 野 } & \text { 将 } & \text { 嗣 } & \text { 新 } & \text { 原 } & \text { 亮 浅 原 利 正 }\end{array}$

初回手術時に反回神経切除施行した症例に対して，再手術時に反回神経再建術を行っ た. 症例は72歳, 女性. 初回手術は甲状腺左葉原発乳頭癌 (Ex2) に対して甲状腺左葉 切除, 左反回神経切除, D $2 \mathrm{~b}$ 郭清を施行された. 5 年後に再発甲状腺乳頭癌と診断され 手術を行った。術中所見は気管左側の食道入口部に $3 \mathrm{~cm}$ の再発腫堭を認め, 摘出術を行 った．左反回神経は前回手術で合併切除されていたが，下咽頭収縮筋を切開して左反回 神経断端を露出した，患側の左頙神経わなも前回手術で切断されていたため，右頸神経 わなを用いて右頸神経わな一左反回神経吻合術を行った。術後 $2-3$ カ月より自覚的に 嗄声が改善し，最長発声時間も経時的に延長した，過去に反回神経切断を行った症例で は, 再手術時に反回神経を同定することは難しく, 神経再建は容易ではない.しかし, 下咽頭収縮筋内での吻合方法や対側頸神経わなの利用で再建可能な症例もあり, 発声機 能改善を目指して試みる価値のある術式と考える.

索引用語：再発甲状腺癌，反回神経，反回神経再建術

\section{緒 言}

近年，術前から反回神経麻罚がある場合でも神経再 建により音声が回復することは広く認知されてい $ろ^{122}$.

今回, 初回手術時に反回神経切除を行った進行甲状 腺癌再発症例に対して, 5 年後に対側の頸神経わなを 用いて反回神経再建を行い，発声機能の良好な改善を 得た 1 例を経験したので，若干の考察を加えて報告す る.

患者 : 72歳, 女性.

$$
\text { 症例 }
$$

主訴：頸部違和感。

既往歴：平成 8 年甲状腺乳頭癌に対して甲状腺左葉 切除, D $2 \mathrm{~b}$ 郭清を行い, このとき左反回神経合併切除 を行った。

家族歴：特記事項なし.

現病歴：平成 14 年に上記主訴で来院し, CT・US 検 查で気管左側, 食道入口部の再発甲状腺癌と診断され

2004年 5 月10日受付 2004 年 6 月10日採用

〈所属施設住所〉

₹730-8655 広島市中区中島町 3-30
た、気管支鏡，上部消化管内視鏡では内腔への浸潤を 認めなかった，左声带は正中位に固定していた。

入院時現症：身長 $157 \mathrm{~cm}$, 体重 $62 \mathrm{~kg}$, 左前頸部に径 約 $3 \mathrm{~cm}$, 弾性硬で圧痛を伴わない腫痹を触知した。

血液生化学検査：末梢血液一般検查, 生化学検查に 異常を認めなかった。

頸部超音波検査：傍気管部に $18 \times 10 \mathrm{~mm}$ の不整形な 結節性病変を認めた（図 $1 \mathrm{~A})$.

頸部 CT 検查：気管を左側から軽度圧排する $20 \times 15$ $\mathrm{mm}$ の軟部陰影を認めた（図 $1 \mathrm{~B}$ ).

上部消化管内視鏡検查：食道内埪への浸潤注認めな かった.

気管支鏡検査：気管内腔への浸潤を認めず，左声帯 は正中位に固定していた。

手術所見：食道入口部付近に約 $3 \mathrm{~cm}$ の再発腫汮を 認め, 食道外膜切除, 腫崵摘出術を行った（図 $2 \mathrm{~A}$, $2 \mathrm{~B}$ ). 左頸神経わなは前回の手術で切除さ机ていた。 神経再建のために，まず右頸神経わなを授動（図 3). 次に下咽頭収縮筋切開して左反回神経切除断端を簬出 し(図 $4 \mathrm{~A}$ )，右頸神経わな一左反回神経吻合術を行っ た（図 4 B).

治療経過：声带機能評価には最長発声時間を用い 


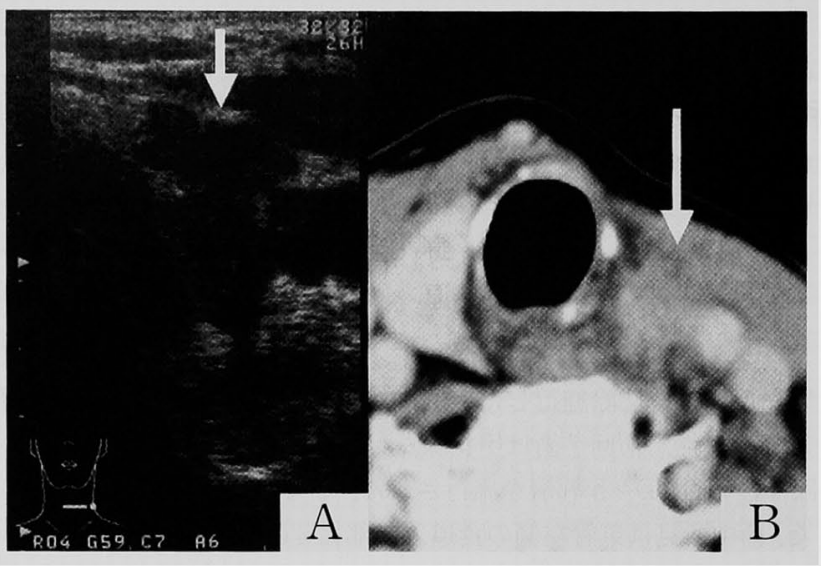

図 $1 \mathrm{~A}$ 頸部 US : 傍気管部に不整形結節性陰影を認め $(\rightarrow)$, 気管と の境界は不明暸化していた。

B 莖部 CT：食道入口部レベルで気管左側に接する $20 \times 15 \mathrm{~mm}$ の腫䡃陰影を認めた $(\rightarrow)$.

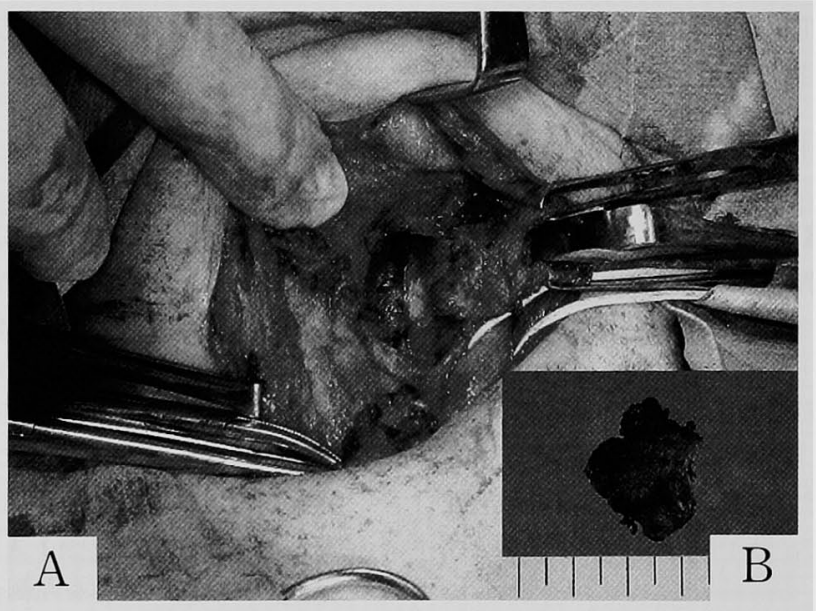

図 $2 \mathrm{~A}$ 術中写真：食道外膜を含めて腫湟を摘出した. 左頸神経わな は前回手術で切断されていた。

B 摘出標本: 約 $3 \mathrm{~cm}$ の多結節性腫瘍. 甲状腺乳頭癌.

た ${ }^{3) 4}$. 術後 $2-3$ 力月より嗄声が自覚的に改善し, 最 長発声時間は術後 3 力月ごろより延長し始め, 11力月 後には術直後の 7 秒から17秒へ改善した（図 5 ).

\section{考察}

進行甲状腺癌の QOL を左右する最大の要素は反回 神経麻痺である，術前から反回神経麻痺がある場合で も神経再建により音声が回復することが多いため，可 能な限り再建術を施行するべきと考える ${ }^{1) 21}$. 初回に反 回神経再建を行うことが原則であるが，前回の手術に
より反回神経が切断されていた場合, 従来は再建術が 不可能と考えられてきた。しかし近年，下咽頭収縮筋 を切開して喉頭入口部末梢で神経断端を同定すること も標準手術として定着しつつあり，マイクロサージェ リーの応用で細径神経の再建も可能となってきた。

しかし, 再手術時の反回神経再建における問題点と して以下の点が挙げられる. (1)初回に反回神経切断を 行った症例では, 再手術時に反回神経が萎縮し同定す ることが難しい. (2)再建に用いる頸神経わななどが切 
除されている場合が多い. (3)進行甲状腺癌症例や局所 再発・浸潤が反回神経喉頭入口部に及ぶ症例では，手 術操作が極めて困難で, 神経再建は容易ではない。

通常反回神経再建術を行った場合, 音声の回復は 6 力月以内に認められる。しかし再手術時に神経再建を 行った場合，音声回復時期に関しては未知数であり， 報告例もない. 本症例では11力月にわたって改善が認 められ，通常より長い観察期間を要すると考える.

進行甲状腺癌では将来再発により反回神経再建を要 することもあり，頸神経わなは極力温存すべきである。 また反回神経浸潤に対して神経剝離温存術を行った場
合は局所再発の可能性が高い.このような場合反回神 経を 2-0 または 3-0 非吸収性モノフィラメント采て マーキングしておくと再発時の神経同定に有用であ る.

反回神経再建が困難な症例には以下の方法を提案す る. (1)反回神経高度浸潤例では下咽頭収縮筋切開し, 喉頭入口部で反回神経を露出して, 神経吻合する2)5). (2)原則として患側頸神経わなを使用するが，郭清など で使用不可能な場合は対側の頸神経わななどを利用す $3^{6) 7}$. (3)神経再建材料として迷走神経，大耳介神経の 間置術など，あらゆるものを利用して再建を試みる81.

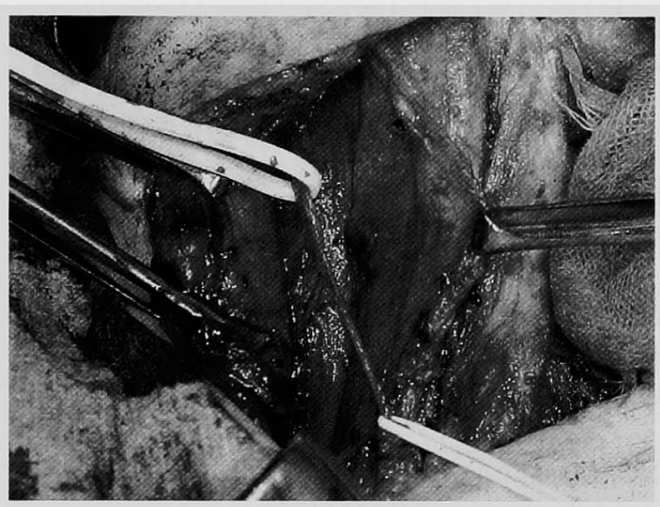

図 3 右䫫神経わな剥離：再建に用いる右頸神経わなを 可能な限り長く剝離した。

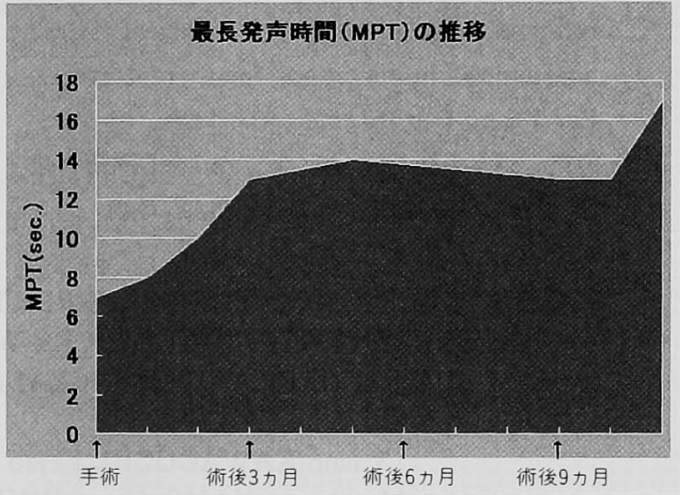

図 5 術後発声機能評価：術後最長発声時間が経時的に延 長した.

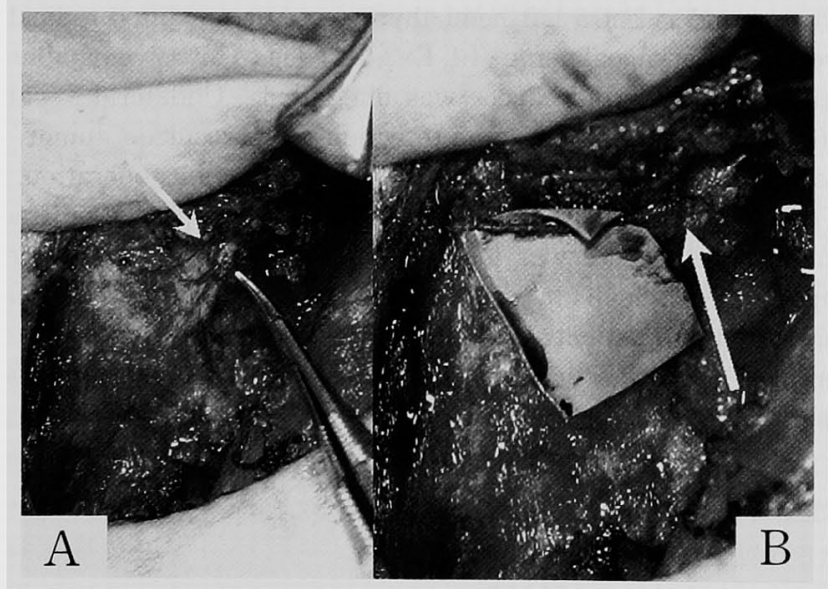

図 $4 \mathrm{~A}$ 反回神経断端の同定：下咽頭収縮筋を切開して，切除されて いた反回神経断端 $(\rightarrow)$ を露出した.

B 右頸神経わな一左反回神経吻合 $(\rightarrow)$ : 露出した左反回神経 断端と，先に授動した右頸神経わなを吻合した。 
これらの方法により再建可能な症例もあり，術後発声 機能改善を期待して試みる価值のある術式と考える.

$$
\text { 結語 }
$$

今回，甲状腺癌初回手術時に反回神経を合併切除し た症例に対して，5年後に再発腫㨖切除，反回神経再 建術を行った，反回神経再建術は下咽頭収縮筋切開に よる対側頸神経わな一反回神経吻合街を施行した。術 後最長発声時間の延長が認められ, QOL は著明に改善 された。

本論文の要旨は，第65回日本臨床外科学会総会（福岡, 2003年)に於いて発表した。

\section{文献}

1) Miyauchi A, Matsusaka K, Kuma K, et al : The role of ansa-to-recurrent-laryngeal nerve anastomosis in operations for thyroid cancer. Eur J Surg Dec $164: 927-933,1998$

2）宮内 昭, 小林毫, 幔 寛二他：反回神経再建 術一特に, 頸神経ワナ反回神経吻合, 手術 54 ：
$1885-1890,2000$

3）沢島政行：発声持続時間の測定. 音声言語医 $7: 23-28,1966$

4) 宮内 昭, 横沢 保, 险 宽二他: 反回神経再建 法の工夫・適応の拡大と声帯機能の評洒法につい て.内分泌外科 $10: 127-132,1993$

5）家根旦有，福田多介彦，細井祐司：音声外科から みた甲状腺手術のコツ。臨外 $56: 1331-1335$, 2001

6）池田莡博，杉野圭三，浅原利正：対側の頸神経ワ 十を利用した反回神経再建術の1例。日臨外会誌 $61: 2891-2894,2000$

7）浜中一敏, 藤森芳郎, 小林信や：反対側頸神経ワ ナに反回神経吻合した甲状腺癌の1例．信州医誌 $48: 183-185,2000$

8）杉野圭三，浅原利正：甲状腺帛分化癌局所再発例 に対する外科治療。臨外 $59: 425-430,2004$

\title{
RECONSTRUCTION OF THE RECURRENT LARYNGEAL NERVE IN A PATIENT WITH RECURRENT THYROID CANCER WHO HAD UNDERGONE RESECTION OF THE RECURRENT LARYNGEAL NERVE IN A PREVIOUS OPERATION
}

\author{
Yasuo KAWAGUCHI, Keizo SUGINO, Masahiro NISHIHARA, \\ Masatsugu YANO, Ryo SHINHARA and Toshimasa ASAHARA* \\ Department of Surgery, Tsuchiya General Hospital \\ *Secona Department of Surgery, Hiroshima University School of Medicine
}

A 72-year-old woman underwent a left hemi-thyroidectomy, modified radical neck dissection and resection of the left recurrent laryngeal nerve (T4, Ex2, N1) due to invasive papillary thyroid carcinoma. Five years later, recurrence of thyroid cancer was diagnosed. Unilateral vocal cord paralysis was observed on bronco-fiber examination. After the resection of the recurrent tumor, reconstruction of the left recurrent laryngeal nerve, which had been resected in the previous operation, was camed out. We could not utilize the left ansa cervicalis because of the previous lymph node dissection. The proximal edge of the recurrent laryngeal nerve was identified by separation of the inferior constrictor. An anastomosis of the right ansa cervicalis to left recurrent laryngeal nerve was performed in front of the trachea. After the operation, the patient's phonation gradually improved and the maximum phonation time recovered. Even in re-operation cases, reconstruction of the recurrent laryngeal nerve is possible and recovery of phonation can be expected. 